\title{
Redescription of Centromerus bulgarianus (Drensky 1931) and Centromerus lakatnikensis (Drensky 1931), (Araneae, Linyphiidae)
}

\author{
by
}

\section{Ch. DELTSHEV*}

Drensky (1931) described two new species, Troglohyphantes bulgarianus and Troglohyphantes lakatnikensis from Bulgarian caves. Later Kratochvil and Miller (1938) revised the description of these species and established that the two species belong to the genus Centromerus. The original description is very superficial and the drawings done inexactly. That is why I consider it necessary to redescribe these species, having had an opportunity to use the type material.

I would like to acknowledge my gratitude to Dr. Hubert of Paris for sending comparative material and to Dr. Saaristo of Turku, who made a comparison of types of Centromerus bulgarianus and $C$. europeus.

\section{Centromerus bulgarianus (Drensky, 1931)}

Troglohyphantes bulgarianus, Drensky 1931, pp. 2, 25-26, 48-47, fig. 5, a-i; Troglohyphantes balcanica Drensky 1931 pp. 2, 41 (nomen nudum); Centromerus bulgarianus (Drensky 1931), Kratochvil and Miller (1938), pp. 1-7, fig. 2, a-e.

\section{Description of maie}

Total length $-1.64 \mathrm{~mm}$. Cephalothorax, length -0.64 , wide $-0.54 \mathrm{~mm}$, paleyellow, convexed.

Eyes completly absent. Clypeus, height $-0.09 \mathrm{~mm}$, slightly concave.

Chelicerae length $-0.32 \mathrm{~mm}$, wide $-0.12 \mathrm{~mm}$, armed with 3 well developed teeth on outer row and 3-4 denticles on inner row.

Sternum, length $-0.36 \mathrm{~mm}$, wide $0.36 \mathrm{~mm}$.

Abdomen, length $-0.82 \mathrm{~mm}$, grey.

Legs, yellowish short, covered proportionally with short fine spines. Femora I with 1 prolateral spine on apical half. Tibiae I-IV with 2 dorsal spines. Metatarsi I-II with small dorsal spine.

Measurements (in $\mathrm{mm}$ ) of legs:

$\begin{array}{lllllll}\text { Leg } & \text { Fe } & \text { Pt } & \text { Ti } & \text { Mt } & \text { Ta } & \text { Total } \\ \text { I } & 1.00 & 0.18 & 0.87 & 0.82 & 0.54 & 3.61 \\ \text { II } & 0.97 & 0.18 & 0.76 & 0.73 & 0.54 & 3.18 \\ \text { III } & 1.00 & 0.18 & 0.91 & & & \end{array}$

* Zoological Institute Bulg. Acad. of Sci., Boul. Rusky 1, Sofia. 
Palpus fig. 1, 2. Tibia and patella each with a stout spine. Paracimbium large, with serrated inner margin. Lamella characteristic small. Basal apophysa forked, like $C$. europaeus.

\section{Description of female}

Total length $-1.74 \mathrm{~mm}$. Cephalothorax, length $-0.73 \mathrm{~mm}$, wide $-0.54 \mathrm{~mm}$, paleyellow.

Eyes completely absent. Clypeus, height $-0.09 \mathrm{~mm}$.

Chelicerae (fig. 3), length $-0.27 \mathrm{~mm}$, wide -0.18 , armed with 2 teeth on outer row and 3-4 denticles on inner row.

Sternum, length $0.36 \mathrm{~mm}$, wide $0.36 \mathrm{~mm}$.

Abdomen, length $-1.00 \mathrm{~mm}$.

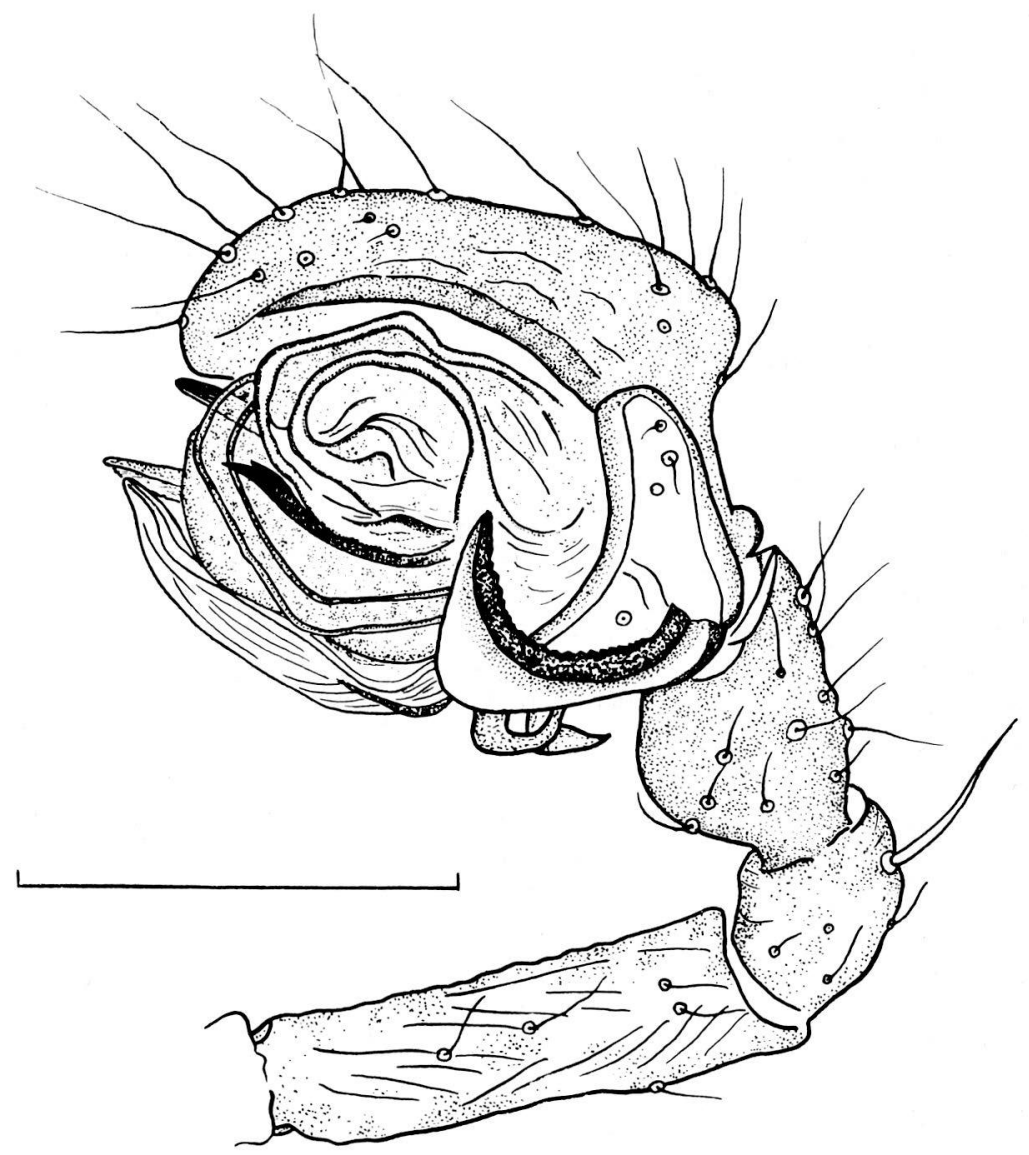

Fig. 1. Centromerus bulgarianus (Dr.). Left ơ palp, external view. 


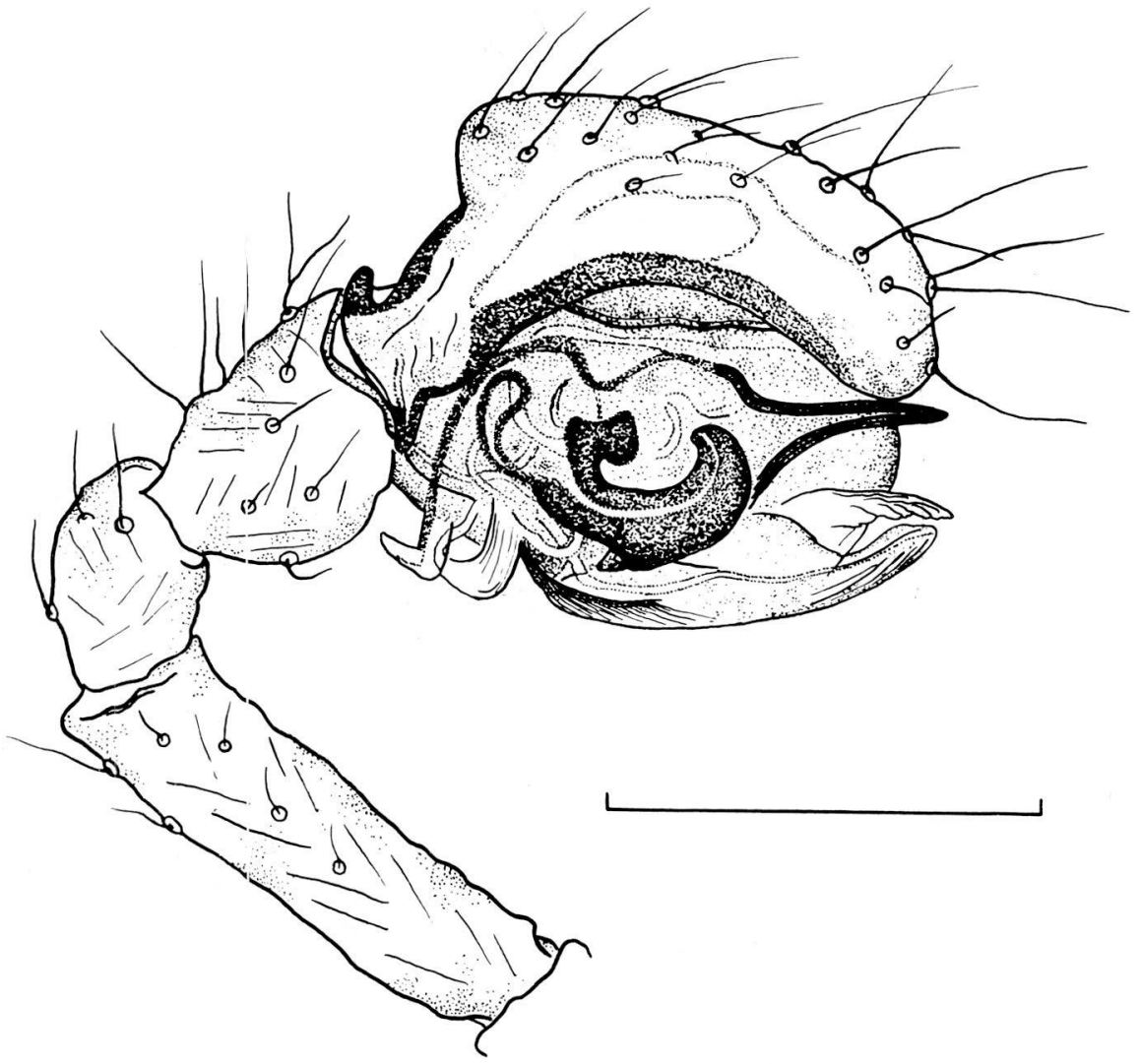

Fig. 2. Centromerus bulgarianus (Dr.). Left $\delta$ palp, internal view.

Legs: Femora I with a prolateral spine on apical half. Tibiae I-IV with 2 dorsal spines. Metatarsi I-II with small dorsal spine

Measurements (in mm) of legs.

$\begin{array}{llllllr}\text { Leg } & \text { Fe } & \text { Pt } & \text { Ti } & \text { Mt } & \text { Ta } & \text { Total } \\ \text { I } & 0.91 & 0.18 & 0.82 & 0.73 & 0.54 & 3.18 \\ \text { II } & 0.91 & 0.18 & 0.75 & 0.64 & 0.45 & 2.92 \\ \text { III } & 0.73 & 0.18 & 0.64 & 0.54 & 0.45 & 2.54 \\ \text { IV } & 0.95 & 0.18 & 0.91 & 0.73 & 0.49 & 3.26\end{array}$

Palpus: Fe - $0.27 \mathrm{~mm}, \mathrm{Pt}-0.18 \mathrm{~mm}, \mathrm{Ta}-0.27 \mathrm{~mm}$. Epigyne (fig. 4) similar to those of $C$. europaeus and $C$. subcaecus. 


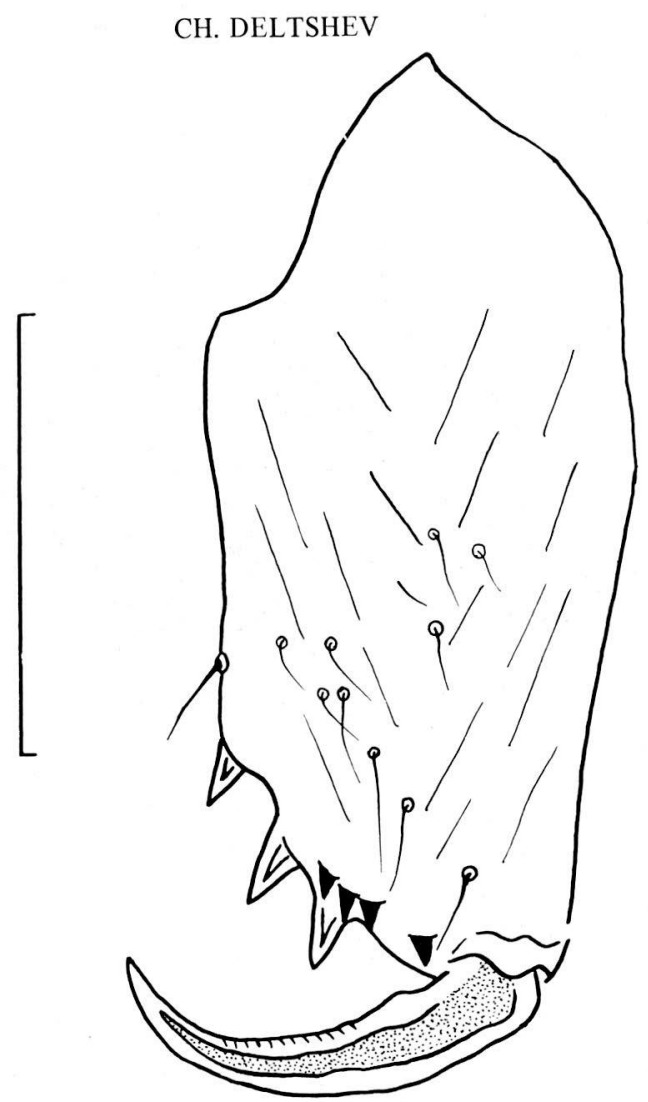

Fig. 3. Centromerus bulgarianus (Dr.), Right ơ palp, posterior view.

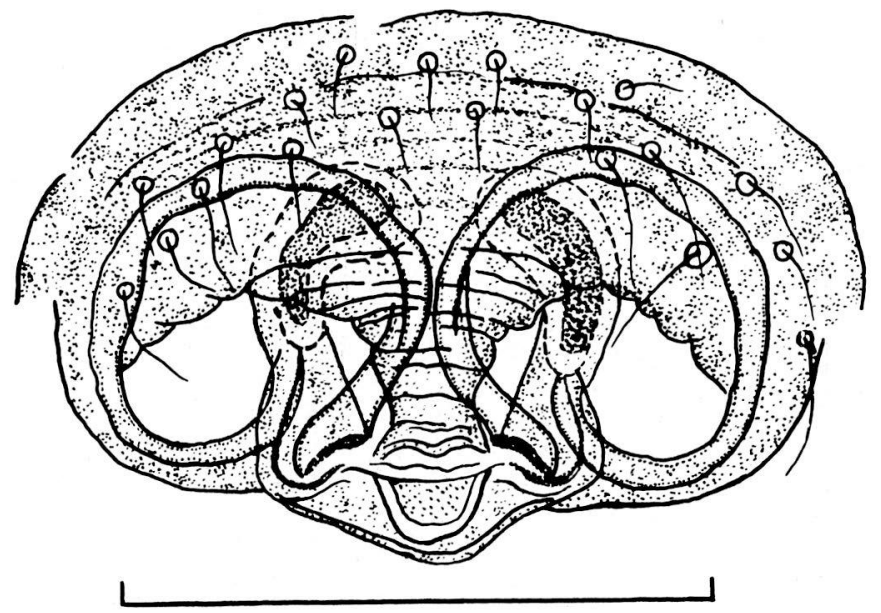

Fig. 4. Centromerus bulgarianus (Dr.). Epigyne. 


\section{DISCUSSION}

Centromerus billgarianus is related to $C$. europaeus and $C$. subcaecus but the three species are readily separated because:

1. There are differences in structure of the basal apophysis.

2. There are a few differences in the structure of the epigyne.

The epigyne of $C$. bulgarianus is bigger than $C$. europaeus (Saaristo in lit. 5.IV. 1972).

3. C.bulgarianus is the largest of the three species.

Material and locality.

"Suchata pestera" cave near the village Lakatnik (district of Sofia), 1 ot lectotype and $39 \%$ paralectotype (leg. P. Drensky); "Sokolskata peštera" near the village of Lutatgik (district of Vraca) 19, 6.II.1967 (leg. P. Beron); "Beljara" cave near the town of Vraca 19, 5.X.1968 (leg. P. Beron).

\section{Centromerus lakatnikensis (Drensky 1931)}

Troglohyphantes lakatnikensis, Drensky 1931, pp. 2, 5, 23-25, 46-47, fig. 4, a-d; Centromerus lakatnikensis (Drensky 1931), Kratochvil and Miller (1938), pp. 2-3, 6-7.

Description of male'.

Total length $-1.92 \mathrm{~mm}$. Cephalothorax, length -0.91 , wide $-0.73 \mathrm{~mm}$, paleyellow.

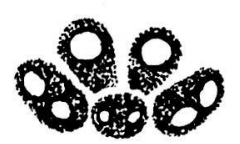

Fig. 5. Centromerus lakatnikensis (Dr.). Eyes (o from in front).

Eyes (fig. 5), well developed, surrounded by a black strip. Posterior row, $0.25 \mathrm{~mm}$ long, median eyes ca one diam. apart and one diam. from laterals. Anterior row, $0.18 \mathrm{~mm}$ long, medians very small and almost approached, ca one diam. from laterals. Clypeus concave, height $-0.09 \mathrm{~mm}$.

Chelicerae, length $-0.36 \mathrm{~mm}$, wide at the base $-0.18 \mathrm{~mm}$, armed with 3 well developed teeth. Posterior row with 3-4 denticles .

Sternum, length $-0.54 \mathrm{~mm}$, wide $-0.49 \mathrm{~mm}$.

Abdomen, length $-1.01 \mathrm{~mm}$, grey.

Legs, yellowish. Femora I with 1 retrolateral spine on apical half. Tibiae I-III with 2 dorsal spines. Tibia IV with 1 dorsal spine. 


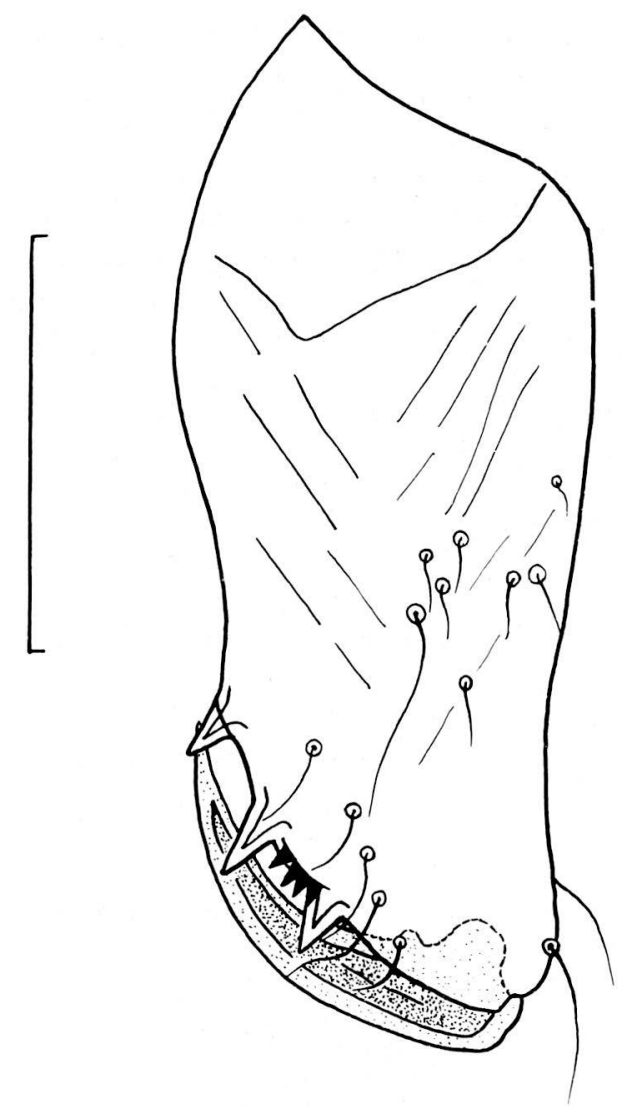

Fig. 6 Centromerus lakatnikensis (Dr.). Right ơ chelicera.

Measurements (in $\mathrm{mm}$ ) of legs:

$\begin{array}{lllllll}\text { Leg } & \text { Fe } & \text { Pt } & \text { Ti } & \text { Mt } & \text { Ta } & \text { Total } \\ \text { I } & 0.82 & 0.21 & 0.73 & 0.49 & 0.40 & 2.65 \\ \text { II } & 0.73 & 0.21 & 0.64 & 0.40 & 0.36 & 2.34 \\ \text { III } & 0.54 & 0.18 & 0.49 & 0.45 & 0.34 & 2.02 \\ \text { IV } & 0.82 & 0.21 & 0.69 & 0.45 & 0.40 & 2.57\end{array}$




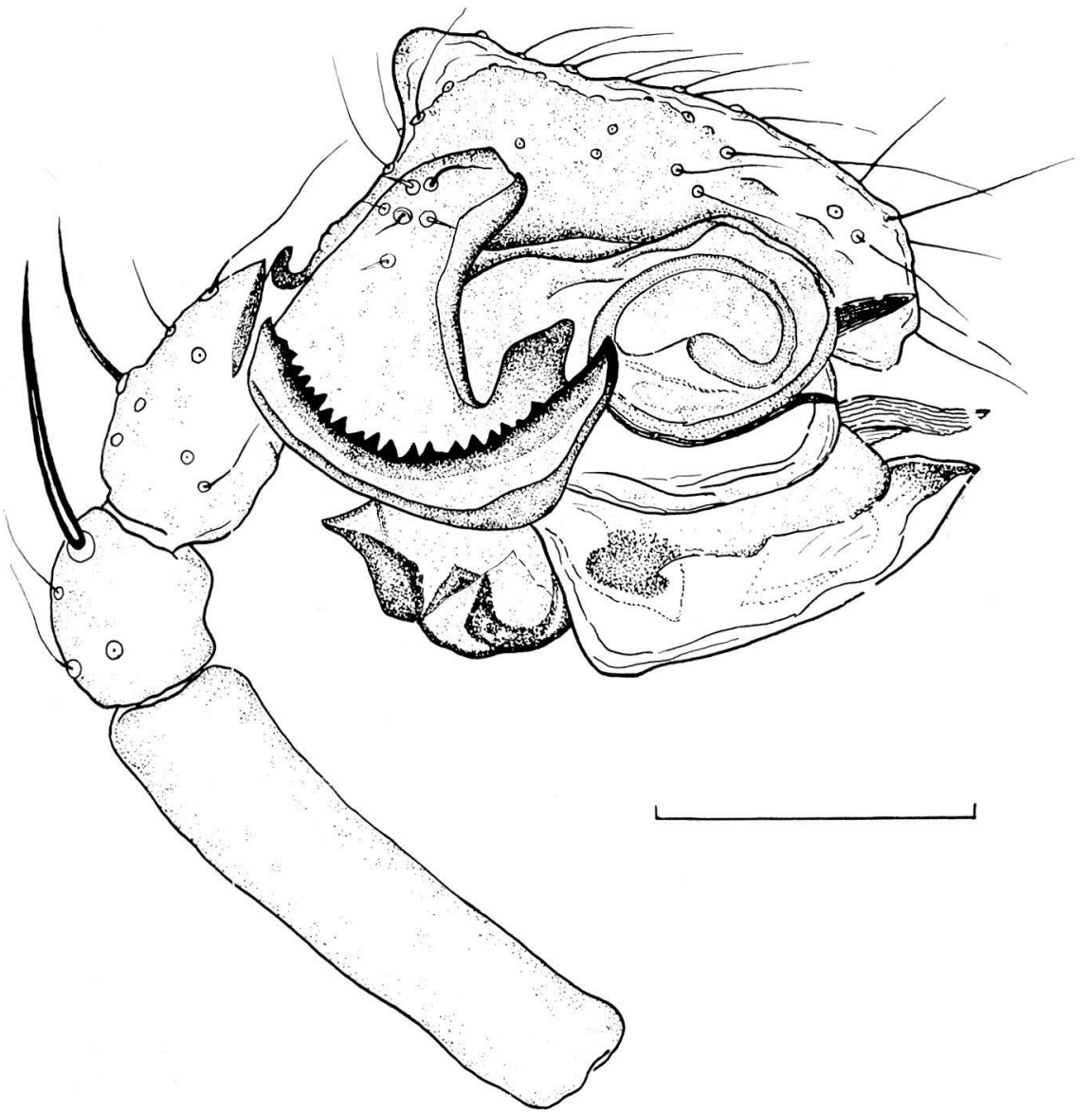

Fig. 7. Centromerus lakatnikensis (Dr.). Right ơ palp, external view.

Palpus (fig. 7,8). Tibia and patella each with a stout spine. Paracimbium is large, toothed along its inner margin. Bulbus similar to those of $C$. albidus and $C$. serratus.

\section{Description of female}

Total length $-2.16 \mathrm{~mm}$. Cephalothorax, length $-0.72 \mathrm{~mm}$, wide $-0.57 \mathrm{~mm}$.

Eyes, well developed, surrounded by a black strip. Posterior row, $0.23 \mathrm{~mm}$ long, median eyes ca one diam. apart and ca one diam. from laterals. Anterior row, $0.17 \mathrm{~mm}$ long, median eyes very small and almost approached, ca. one diam. from laterals. Clypeus, height $-0.05 \mathrm{~mm}$. 


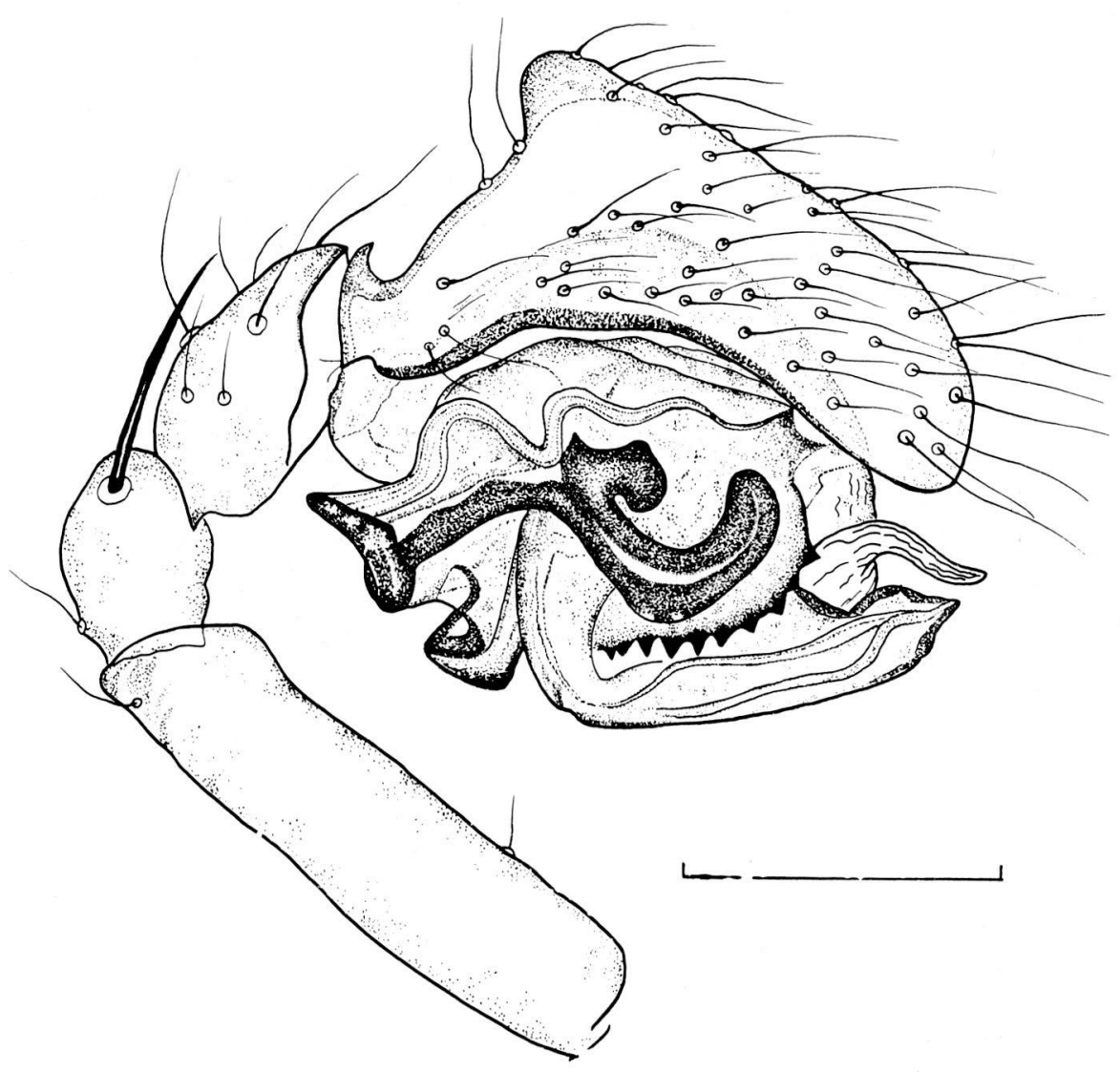

Fig. 8. Centromerus lakatnikensis (Dr.). Left ơ palp, internal view.

Chelicerae, length $-0.32 \mathrm{~mm}$, wide $0.14 \mathrm{~mm}$, armed with 3 well developed teeth. Posterior row with 3-4 denticles.

Sternum, length $-0.57 \mathrm{~mm}$, wide $-0.55 \mathrm{~mm}$.

Abdomen, length $-1.40 \mathrm{~mm}$, grey.

Legs: Femora I with 1 retrolateral spine on apical half. Tibiae I-III with 2 dorsal spines. Tibia IV with 1 dorsal spine.

Epigyne presented on fig. 9. Vulva presented on fig. 10. The epigyne is very similar to those of C.albidus and $C$. quercicola. 


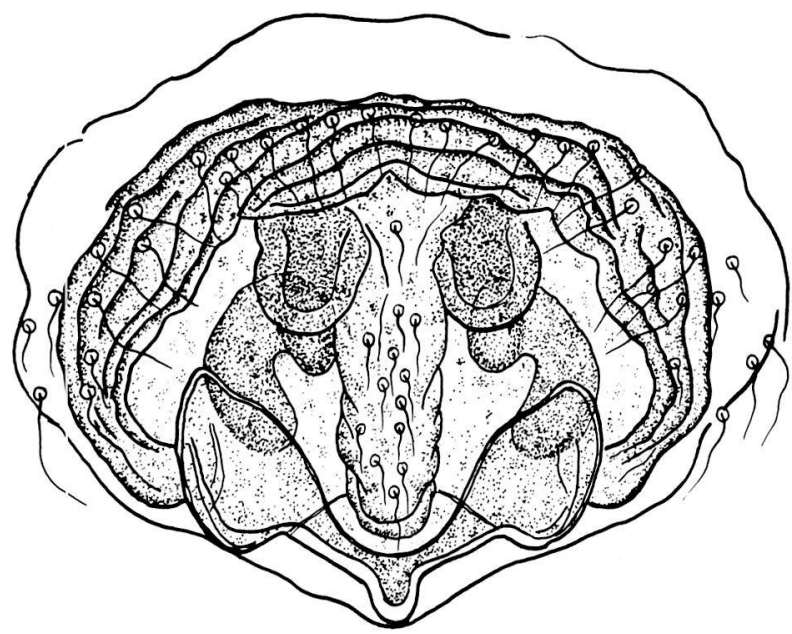

Fig. 9. Centromerus lakatnikensis (Dr.). Epigyne.

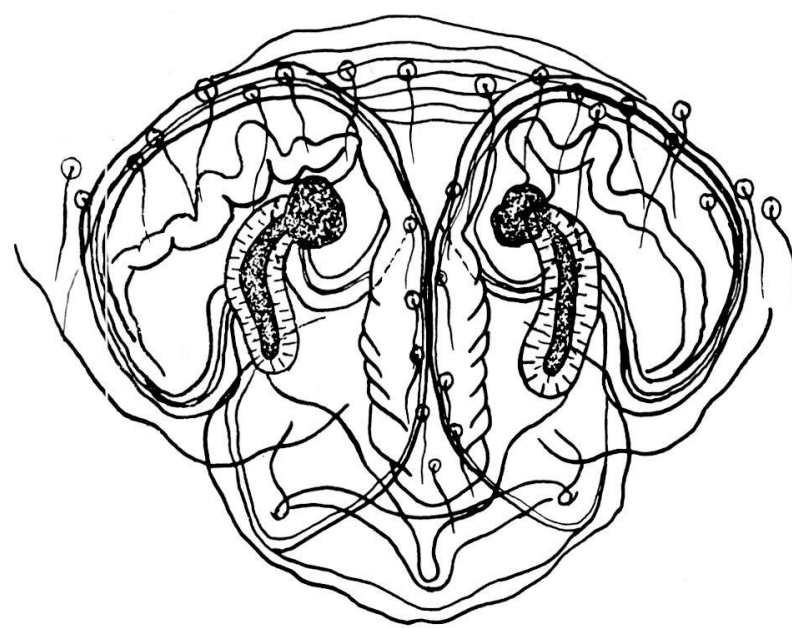

Fig. 10. Centromerus !akatnikensis (Dr.). Vulva. 


\section{DISCUSSION}

Centromerus lakatnikensis is related to $C$. albidus, but $C$. albidus is smaller and there are a few differences in the structure of the epigyne.

Material and locality.

"Suchata peštera" near the village of Lakatnik (district of Sofia), 1 \% lectotype, 3 o paralectotype, 23. III. 1930 (leg. P. Drensky); 20̛ , 5.XI. 1970 (leg. Ch. Deltshev); "Radjova Jama" pot near the village of Millanovo (district of Sofia), 2qo, 3. XII. 1961 (leg. P. Beron).

By examining type-material of Centromerus lakatnikensis, it was established, that the species is very related to C. albidus, described by Simon 1929. The comparative material from $C$. albidus, which was sent to me, was very insufficient (19) and that did not give me a ground to synonymised $C$. lakatnikensis.

In the meantime while the article was in press, Dr. Moritz (to whom I had sent material from $C$. lakatnikensis) established (in litt.) that the two species are identical.

\section{SUMMARY}

The type specimens (lectotypes) of Centromerus bulgarianus and $C$. lakatnikensis, preserved in the collection of the Zoological Institut - BAN, Sofia, are redescribed. The redescription is necessary, because the original description is superficial and the drawings are inexact. Moreover, the male of $C$. lakatnikensis was unknown.

\section{RÉSUMÉ}

Les exemplaires du type (lectotypes) de Centromerus bulgarianus et C.lakatnikensis, conservés dans la collection de l'Institut Zoologique - BAN, Sofia sont décrits de nouveau. La nouvelle description originale est indispensable parce que la description originale est très superficielle et les figures ne sont pas précises. De plus, le mâle de $C$. lakatnikensis était inconnu.

\section{LITERATURE}

Drensky, P. - 1931 - Höhlen-Spinnen aus Bulgarien. Rev. Bulg. Acad. of Sci., XLIX. Sofia. Kratochvil, J., Miller F. - Sur le problème des araignées Cavernicoles du genre Centromerus de la péninsule Balkanique. Bull. Inst. roy. Hist. Natur. Sofia XI. 